IZA DP No. 9883

Mining in Arctic and Non-Arctic Regions:

A Socioeconomic Assessment

Anders Frederiksen

Maja Due Kadenic

April 2016 


\title{
Mining in Arctic and Non-Arctic Regions: A Socioeconomic Assessment
}

\author{
Anders Frederiksen \\ Aarhus University \\ and IZA \\ Maja Due Kadenic \\ Aarhus University
}

Discussion Paper No. 9883

April 2016

IZA
P.O. Box 7240
53072 Bonn
Germany

Phone: +49-228-3894-0

Fax: +49-228-3894-180

E-mail: iza@iza.org

\begin{abstract}
Any opinions expressed here are those of the author(s) and not those of IZA. Research published in this series may include views on policy, but the institute itself takes no institutional policy positions. The IZA research network is committed to the IZA Guiding Principles of Research Integrity.

The Institute for the Study of Labor (IZA) in Bonn is a local and virtual international research center and a place of communication between science, politics and business. IZA is an independent nonprofit organization supported by Deutsche Post Foundation. The center is associated with the University of Bonn and offers a stimulating research environment through its international network, workshops and conferences, data service, project support, research visits and doctoral program. IZA engages in (i) original and internationally competitive research in all fields of labor economics, (ii) development of policy concepts, and (iii) dissemination of research results and concepts to the interested public.
\end{abstract}

IZA Discussion Papers often represent preliminary work and are circulated to encourage discussion. Citation of such a paper should account for its provisional character. A revised version may be available directly from the author. 
IZA Discussion Paper No. 9883

April 2016

\section{ABSTRACT \\ Mining in Arctic and Non-Arctic Regions: A Socioeconomic Assessment}

In this paper, we study how mines change local societies in the Nordic countries with a particular focus on the Arctic region. Our study is based on register data at the municipality level from Norway, Sweden, and Finland for the period 1986 to 2013. The applied econometric model allows for identification of the total socioeconomic effects that occur throughout the mine's life cycle. We find positive effects on local employment and reductions in unemployment and the number of people outside the labor force when a mine is opening up. We also detect significant shifts in the industry structure in the period around a mine opening and we find that mines attract young people and reduce crime rates. We do not find any effects on the local population size, the gender or education compositions, or fertility rates.

JEL Classification: J2, J15, O12

Keywords: mining, Arctic, socioeconomic effects, resource development, Nordic countries

Corresponding author:

Anders Frederiksen

Aarhus University

Birk Centerpark 15

7400 Herning

Denmark

E-mail: afr@asb.dk 


\section{Introduction}

The Arctic region attracts renewed attention from extractive industries, oil companies, and governments from around the world. The rush to the Arctic is motivated by a growing pressure on existing resources, the receding ice cap, and technological advances that open up new opportunities in the Arctic. At present there are extractive activities in the Scandinavian, Russian, and North American sections of the Arctic (Harsem, Eide, and Heen, 2011) and the Arctic states are promoting natural resource development as a strategy for creating local employment and national economic growth (Kullerud, 2011). Our intention with this paper is to broaden the perspective even further. We will do so by empirically establishing the socioeconomic effects of mining in the Arctic and by assessing how such effects differ from those observed in non-Arctic regions.

We focus our analysis on the unique Nordic setting where high-quality register data is available and where the countries have mining activities both in Arctic and non-Arctic regions. The detailed register data allow us to study a broad set of socioeconomic variables such as population size, employment, industry structures, the demographic composition (including fertility), educational composition, and crime rates. While our results are important to the Nordic countries (Sweden, Norway, and Finland) we study, they are also relevant to other countries such as Canada, the USA, and Russia who have mining activities in the Arctic region, and even to Greenland where there are limited mining activities at present, but where a large-scale mine often is suggested as the path toward economic growth. ${ }^{1}$

Extractive industries have been studied extensively outside the Arctic region where resource abundance has been linked to macroeconomic performance (Sachs and Warner, 1995, 1999, 2001). Sachs and Warner's (1995) prominent paper presents evidence which suggests that countries with a high ratio of natural resource exports tend to have lower growth rates. Other researchers argue, however, that the "resource curse" is the exception rather than the rule and the evidence about the relationship between economic growth and natural resource extraction is contradictory (Davis, 1995, 1998, 2010). While economists and researchers within other social science disciplines have examined the macro-level effects of mineral development, knowledge about the effects of extractive industries on regional and local development is more scarce (McMahon and Remy, 2001; Rolfe et al., 2011; Gilberthorpe and Papyrakis, 2015). Nevertheless, at this level extractive industries are commonly found to benefit local societies both within and outside the Arctic region through increased employment (AMAP, 2010; McMahon and Remy, 2001; Carrington, 1996; Aroca, 2001; Hajkowicz, Heyenga, and Moffat, 2011). Our analysis operates at this micro level with a focus on how mines influence local socioeconomic variables.

When assessing the effects of mines it is important to consider the mine's life cycle (Kadenic, 2015). For example, a strict focus on the socioeconomic effects that result from a mine in operation would miss the effects on society that result from, say, the labor-intensive construction phase. Hence, to identify the total effects of a mine on the local society we apply the econometric model developed in Jacobson, LaLonde, and Sullivan (1993). This methodology is particularly suitable for the present analysis as it can be used to establish both the effects that occur prior to the official mine opening and the effects of the mine when it is in operation.

\footnotetext{
${ }^{1}$ This argument is promoted by several interest groups such as governmental bodies, advisory groups, and business associations. See Government of Greenland, 2014; Ministry of Foreign Affairs, 2011; Økonomisk Råd, 2012; The committee for Greenlandic mineral resources to the benefit of society, 2014; Copenhagen Economics, 2012; Nuttall, 2012.
} 
Our empirical results, which are based on municipality-level register data from Norway, Sweden, and Finland from 1986 to 2013, show clear and positive employment effects in the municipality where a new mine is established. These employment effects start to show one year before the mine begins operation and they are persistent. In addition to the positive effect on employment, the opening of a new mine lowers unemployment and reduces the number of people who are outside the labor force. The reduction in unemployment coincides with the increase in employment, but the reduction in the number of people who are outside the labor force occurs much later. We do not find any effects on population size in response to a mine opening. Most importantly, these effects are similar for Arctic and non-Arctic municipalities.

Mines also have important effects on the industry structure and these effects differ between Arctic and nonArctic municipalities. In the Arctic region the employment share allocated to the mining industry starts to grow in the year the mine starts production (and not earlier). Three years after the mine starts to operate it has increased the employment share in the mining industry by as much as 3.1 percentage points. This result for the Arctic municipalities stands in stark contrast to the results pertaining to non-Arctic municipalities, where a mine opening has no significant effect on the employment share allocated to the mining industry.

Furthermore, in Arctic municipalities the employment share allocated to the construction industry grows prior to and during the year the mine starts production and then again in year three after the mine opening. Non-Arctic municipalities only experience an increase in the employment share allocated to the construction industry in year three after the mine opening. The primary sector also grows in response to mining activities, but the pattern is different. For this sector the employment share increases by 2.4 percentage points in the year prior to the mine opening and it stays at this higher level thereafter in both Arctic and non-Arctic municipalities.

The mines attract young people. The positive effect of a mine opening on the number of people aged 20 to 39 can be detected up to three years before the mine starts production and it remains positive up to three years after the mine opening (but the effect is only statistically significant through the year where the mine starts operation). One could expect that this result was due to an inflow of young men, but that is not the case. The opening has no significant effect on the gender composition in the municipality. Further, we find no effects from a mine opening on birth rate or the level of human capital in a municipality. But, we do identify a reduction in crime rates.

The remainder of the paper is organized as follows. In the next section we present the Arctic region, which is followed by a discussion of the socioeconomic effects of mining in the Arctic and elsewhere. In Section 4 we present data on the mines and the register data applied in the empirical section of the paper. In Section 5 we discuss our empirical strategy, and our results are presented in Section 6. Implications are discussed in Section 7. Section 8 concludes.

\section{The Arctic region}

Arctic societies depend on export of natural resources, subsistence activities, and transfer payments (Aarsæther, 2004; Duhaime, 2004; Huskey and Pelyasov, 2015). The three pillars of the Arctic economy represent two different development models according to Duhaime and Caron (2006), which are characterized by exploitation of either renewable resources (marine resources or forestry) or nonrenewable resources (hydrocarbons and minerals). 
The mining activities around the Arctic are presently an important contributor of raw materials to the world economy. The greatest quantity of these minerals is extracted by Russia, mostly on the Kola Peninsula and in Siberia, and they include copper, nickel, tin, apatite, platinum, gold, and diamonds (Huntington and Weller, 2005). Mining in the Canadian Arctic is for copper, lead, zinc, gold, and diamonds (Huntington and Weller, 2005), and Alaska has one of the largest and richest zinc mines in the world (Capozza, 2005). Adding to this is Scandinavia's long history of mining and exploration in the Arctic regions of Norway, Sweden, and Finland (FODD, 2012). Mineral extraction has also taken place in Greenland from the 1800s up to modern times (Nordregio, 2010). The Greenlandic mines, however, have been relatively small compared to mining activities in other parts of the Arctic region.

The Arctic economy is large compared to its share of population, with a GDP per capita of USD 45,360 in 2010, which is greater than most European countries but comparable to the United States (Huskey and Pelyasov, 2015). The total Arctic GDP was USD 442.8 billion in 2010. Furthermore, the Arctic had 0.15 percent of the world's population and produced 0.6 percent of world GDP in 2010. Hence the contribution to world output was four times the share of population (Huskey and Pelyasov, 2015). The total population of the Arctic is just above 4 million. According to the recent Arctic Human Development Report (AHDR, 2015), population growth was slowest between year 2000 and 2010 in the Scandinavian Arctic (Norway by 0.6 percent; Sweden -1.0 percent; and Finland 1.4 percent), with the exception of Russia, which accounts for the largest population decline of -5.3 percent. The Canadian Arctic, Alaska, and Iceland experienced relatively high population growth of roughly 13 percent during the same period.

Employment during the 2000 to 2010 period was increased in the Arctic regions of Norway by 7.8 percent, Sweden 3.8 percent, and Finland 8.2 percent, while the Canadian Arctic and Alaska had employment increases of 21.3 percent (Canadian Arctic) and 13.9 percent (Alaska). For more details, see Huskey and Pelyasov (2015). Both Iceland and the Russian Arctic experienced moderate employment growth of 6.8 percent (Iceland) and 5.3 percent (Russian Arctic), while the Danish regions of Arctic (Greenland and Faroe Islands) had an employment decline of -5.5 percent but a population growth of 3.1 percent (Huskey and Pelyasov, 2015).

Fertility rates of the Arctic regions of Norway, Sweden, and Finland are below the replacement level of 2.1, whereas Alaska, the Arctic region of Canada, and Faroe Islands have fertility rates above the replacement level. The Arctic has a relatively high male gender ratio due to an economy that is based on fishing and resource extraction (Heleniak and Bogoyavlensky, 2015). Furthermore, the Arctic regions of the Nordic countries have the highest median age, the smallest youth shares, relatively high portions of pension-age persons, and low proportions of people in the working age compared to the rest of the Arctic (Heleniak and Bogoyavlensky, 2015).

Finally, education, which is an essential part of human development and an important contributor to economic growth and well-being, is unequally spread across the Arctic region. Arctic regions of Scandinavia and Russia have relatively large shares of the population with post-secondary educations, while Alaska and the Canadian Arctic have relatively low levels (Hirshberg and Petrov, 2015).

\section{Socioeconomic effects of mining}

Mining features in the history of local community and regional development in several parts of the world. Examples are copper mining in northern Chile; $19^{\text {th }}$-century growth in Western Australia and the state of 
Victoria; silver and gold mining in the Rocky Mountain region in the United States; diamond and gold mines in Johannesburg in South Africa; and iron-ore mining in the region around Kiruna in northern Sweden (Eggert, 2001). Furthermore, studies show that the resource industry more generally has been a strong direct contributor to the economic development in remote regions (Rolfe et al., 2011).

The empirical literature on the effects of mining activities is very diverse. Some papers focus on economic and demographic aspects and study the relationship between resource abundance and regional economic and demographic effects throughout regions such as Chile, Australia, Sweden, US states, and Spain (Aroca, 2001; Rolfe et al., 2011; Ivanova 2014; Ejdemo, 2013; Papyrakis and Gerlagh, 2007; Domenech, 2008). Some of these studies identify how mines contribute to the GDP of a region; others take a more narrow focus and measure employment effects (Eggert, 2001; Rolfe et al., 2007). These employment effects can often be decomposed further by sector (Aroca, 2001; Loveridge, 2004; Clements, Ahammad, and Qiang, 1996). Cross-regional socioeconomic analyses of mining also include measures such as unemployment rates, population size, and educational attainment (Tonts, Plummer, and Lawrie, 2012; Hajkowicz et al., 2011).

It is important to stress that besides direct employment at the mine, additional indirect employment is created through contractor and service industries, and induced jobs are created through consumption spending (Rolfe et al., 2007; Ejdemo, 2013). Studies establish a link between employment effects in the mining sector and other sectors including the service sector, utility sector, transportation sector, wholesale and retail trade sector, and manufacturing sector (Hajkowicz et al., 2011; Aroca, 2001; Ejdemo, 2013). These linkages include purchase of inputs such as food and catering services, transportation services, electricity, and materials. For example, a related empirical study of the Alaskan labor during the development of the TransAlaska Pipeline System shows increases in population, employment growth, unemployment reduction, and labor demand increases in construction, transportation, services, retail trade, finance, insurance, and real estate; while the manufacturing industry and government sector were unaffected (Carrington, 1996).

A new trend that has arisen during the past two decades is that mining companies have shifted their way of operation by reducing the provision of mining towns toward outsourcing and a greater use of local contractors and business suppliers (MMSD, 2002; Rolfe et al., 2007). Outsourcing creates a new productive base of new small- and medium-size firms that start by providing their goods and services to the mining company and eventually expand their business to other sectors in the region and exploit markets outside the mining sector (Aroca, 2001). The regional suppliers of mining input extend the linkages by purchasing their own inputs within the region, which additionally stimulates regional economic activity. Further stimulation of the region's economic activity is created when miners spend their household incomes on goods and services within the region (Eggert, 2001).

Mining activities have also proven to influence human capital. For example, a cross-regional study of 71 local government regions in Australia reports that mining activities are positively associated with educational attainment (Hajkowicz et al., 2011). This finding is also established by MMSD (2002). However, a macrolevel study shows that natural resource abundance correlates negatively with educational measures, which relates to the explanation that natural resource-based industries often rely on low-skill labor (Gylfason, 2001).

An additional set of socioeconomic indicators affected by mining activities are developed by the Arctic Social Indicators (ASI) Project as a response to the Arctic Human Development Report (AHDR) to track changes in human development in the Arctic (ASI, 2010; AHDR, 2004). Amongst these indicators are several population indicators, including total population (broken down by age and gender when possible) and 
number of births. Finally, Carrington's Alaskan study shows that influx and presence of young single men led to increased crime (Carrington, 1996), a finding supported by McMahon and Remy (2001) and MMSD (2002).

The general picture arising from these prior studies is that extractive industries (and mines in particular) have a broad impact on local socioeconomic activities. These range from effects on population size, over employment and the employment structure, to crime rates. Adding to the complexity is the fact that these effects change over the life cycle of the mine. The reason is that a mining project is initiated years before the mine starts operation and it goes through five phases (Cusumano, Kahl, and Suarez, 2006; Kadenic, 2015; Storey and Hamilton, 2003; Moon and Evans, 2006). The first phase in a typical life cycle of a mining project is exploration, which covers activities such as, drilling, geological mapping, sampling, and testing. This phase is followed by a planning phase, which focuses on feasibility studies and regulatory approval processes, including cost analyses and technical studies to prove the commercial viability, environmental and social impact assessments, and community hearings. Many of these preparatory studies can be and are done remotely by third-party consultants and have a minor effect on local economic activities. The following phase is construction. During this phase local activities are significant and involve construction of the production facilities and camps and setting up of appropriate infrastructure. Despite the direct relation to the mine, these activities may not necessarily be categorized as mining activities in official registers and may instead show up as increased employment in the construction and transportation industries, i.e., as indirect employment. The next phase is the actual commencement of operating the mine, the operation phase, where the raw material is extracted and processed. The final phase is closure, which includes remediation and restoration of site. A study of the socioeconomic effects of mines therefore should be sufficiently broad and flexible such that it can capture the diversity of effects and the fact that such effects may vary throughout the life cycle of the mining project.

\section{Data}

In this section we describe the data used in the empirical analysis. We use register data provided by the statistical bureaus from the three Nordic countries: Norway, Sweden, and Finland. This information is complemented with data from the Fennoscandian Ore Deposit Database (FODD), which contains information about mines in the region, their location, mining history, tonnage, and commodity grades of deposits.

\subsection{Nordic mines}

Extensive exploration and large mining operations are currently taking place throughout Scandinavia (see Table 1). There are 34 active mines across Finland, Norway, and Sweden and 24 mines are located in the Arctic region. The mines are spread unequally across the three countries with 5 active mines in Norway, 13 active mines in Finland, and 16 active mines in Sweden.

The Arctic region of Norway comprises Nordland county, Troms county, and Finnmark county and contains 4 mines. The Arctic region of Sweden comprises Västerbotten county and Norrbotten county, where 12 mines are located. The Arctic region of Finland is made up of Lapland and Oulu, and these regions contain 8 mines. The Swedish mines are mainly extracting iron $(\mathrm{Fe})$, zinc $(\mathrm{Zn})$, and copper $(\mathrm{Cu})$, the mines in Norway are primarily extracting iron (Fe), and the mines in Finland are mainly extracting nickel (Ni), zinc (Zn), copper $(\mathrm{Cu})$, and gold $(\mathrm{Au})$. 
[Table 1 around here]

\subsection{Register data}

The register data is obtained from publicly available databases at Statistics Norway, Statistics Sweden, and Statistics Finland or they have been acquired directly from these statistical bureaus. The data is thus of the highest possible quality.

To identify the effects of mines on local societies we use data at the municipality level. In our main sample (spanning 1995 to 2012) there are 1023 municipalities (see Table 2). ${ }^{2}$ There are 174 municipalities located in the Arctic and 849 are non-Arctic municipalities. While the Arctic municipalities are relatively small with 9,000 inhabitants on average, the non-Arctic municipalities have an average size of 20,000 inhabitants. There is also some variation in municipality size across countries. The 290 municipalities in Sweden have on average 32,000 inhabitants. The 422 municipalities in Norway and the 311 municipalities in Finland are smaller and have on average 11,000 inhabitants.

[Table 2 around here]

Motivated by the literature review, we will, in the empirical analysis, make use of a large set of dependent variables to establish how local municipalities in the Arctic and the non-Arctic regions change when mines start to operate in the area. Our focus will be on population size, employment, unemployment, and the people outside the labor force, but we will also assess to what extent mines influence the industry composition and the gender, age, and educational compositions, and to what extent mines change fertility and crime rates. An overview of the used dependent variables is presented in Table 3.

[Table 3 around here]

The data series that we have obtained vary in length. Demographic variables such as population size, age, and gender are available in all countries from 1986 and we can use this information through 2013. Information on employment is available in all countries for the period 1995 to 2012 and information on education is available from 1987 to 2012. The shortest time series that we use are on crime and they span the period 2007 to 2012. The time periods used in regressions are presented in Table 3 and all regression tables contain information about the time period used.

\section{Methodology}

In the above section we stressed that it is important to take the life cycle of the mine into account when assessing the effects of a mine on the local society. For example, a study that ignores activities prior to the opening date of the mine would leave out the important and labor-intensive construction phase. To accommodate this issue we apply a particular econometric framework developed in Jacobson et al. (1993). The advantage of this methodology is that it allows us to identify all effects from the mining activityeffects that occur prior to, during, and after the mine starts operation. ${ }^{3}$

\footnotetext{
${ }^{2}$ We have deleted the smallest municipalities from our analysis. Hence, we focus our analysis on municipalities with at least 500 inhabitants. Throughout the sample period there has been multiple municipality mergers. We have accounted for this by merging data from the individual municipalities that merge in the time periods prior to the merge.

${ }^{3}$ As will become clear below, we focus on the time period around a mine opening, i.e., the period that spans three years prior to a mine opening to three years after the mine starts operation. The "event" that we study is thus a mine opening.
} 


\subsection{The econometric model}

The methodology developed in Jacobson et al. (1993) allows us to estimate the total effect the mine has on municipality-level outcomes (population, employment, etc.). These effects are identified as the differences between how the municipality would have progressed without the mine (the expected outcome) and how it is developing with the mine (the actual outcome).

To capture these effects we construct a set of dummies that will be included in the econometric model. Let the dummy $D_{i t}^{0}=1$ if the mine in municipality $i$ starts producing in year $\mathrm{t}$ and let the dummies $D_{i t}^{k}=1$ if, in period $t$, the time distance to the opening of the mine in municipality $i$ is $k$ years. We use $k<0$ to denote periods prior to the mine opening and $k>0$ to indicate periods where the mine is producing. In our preferred specification we allow $k$ to vary from -3 to 3 .

In the econometric model the dependent variable $y_{i t}$ (e.g., the population in municipality $i$ at time $t$ ) is explained using the dummies constructed above and a time trend intended to capture macroeconomic changes:

$$
y_{i t}=\alpha+\gamma_{t}+\sum_{k=-m}^{m} D_{i t}^{k} \delta_{k}+\varepsilon_{i t}
$$

In this specification $\alpha$ is a constant term, $\gamma_{t}$ are year dummies (i.e. the trend), and $\varepsilon_{i t}$ is an error term. The full effect of the mining activities is captured by the combined effects of the $\delta_{k} s$.

It is well known that municipalities may differ among themselves and that municipalities located in the Arctic region are different from other municipalities. Arctic municipalities are in general scarcely populated and, as discussed in AHRD (2015) (and supported by our data), they do not experience the same growth in population as non-Arctic municipalities. Ignoring such differences in levels and trends between Arctic and non-Arctic municipalities would provide misleading estimates of the effects of mines. Hence, to accommodate this, we extend the initial model along two dimensions. We introduce a municipality fixed effect $\left(\alpha_{i}\right)$ to account for level differences across municipalities, and we add municipality-specific trends $\left(\omega_{i} t\right)$ :

$$
y_{i t}=\alpha_{i}+\omega_{i} t+\gamma_{t}+\sum_{k=-m}^{m} D_{i t}^{k} \delta_{k}+\varepsilon_{i t} .
$$

This highly flexible model will produce unbiased estimates of the effects of mines on the dependent variable even if the decision to locate the mine in a particular municipality depends on fixed characteristics of the municipality (this could be its geographical location in terms of longitude, latitude, or distance to water) and previous trends in the municipality. ${ }^{4,5}$

\footnotetext{
Had the data permitted it would have been natural to extend the period of study. We have also attempted to study the event of a mine closure, but it proved infeasible to conduct a proper statistical analysis due to the low number of mine closings in the sample period.

${ }^{4}$ For a detailed discussion of this, see the original paper by Jacobson et al. (1993).

${ }^{5}$ It can be noted from Table 1 that some municipalities have more than one mine. In such as case we estimate the effect of a new mine opening in the area conditional on the municipality fixed effect and trends. In a sensitivity study we have also included an additional variable reflecting the number of mines in a municipality and reassuringly all results were qualitatively equivalent to reported results presented below.
} 
A final adjustment to the model is made to accommodate the possibility that the effects of mines may be different between Arctic and non-Arctic municipalities. For this reason, we include interaction terms between the dummy variables described above and a dummy for being an Arctic municipality. Hence, our final econometric specification:

$$
y_{i t}=\alpha_{i}+\omega_{i} t+\gamma_{t}+\beta * \operatorname{Arctic}_{i}+\sum_{k=-m}^{m} D_{i t}^{k} \delta_{k}+\operatorname{Arctic}_{i} * \sum_{k=-m}^{m} D_{i t}^{k} \gamma_{k}+\varepsilon_{i t},
$$

Where $\operatorname{Arctic}_{i}$ is a dummy variable taking on the value 1 if it is an Arctic municipality and 0 otherwise. The terms: $\operatorname{Arctic}_{i} * \sum_{k=-m}^{m} D_{i t}^{k} \gamma_{k}$ represents the interactions between Arctic municipality and the dummies introduced earlier. Now, the effect of the mine is captured by the combined effects of the $\delta_{k} s$ and the $\gamma_{k} s$. Further, the $\delta_{k} s$ capture the "general" effect of a mine applicable to all municipalities whereas the $\gamma_{k} s$ identify to what extent the effect of mines are different for Arctic municipalities. That is, if all $\gamma_{k} s=0$, then there is no difference in such effects between Arctic and non-Arctic municipalities.

\section{Results}

In this section we establish how mines change local societies and we focus on how these changes are different between Arctic and non-Arctic municipalities. We find significant employment effects and a clear shift in the industry structure toward mining-related activities - such effects appear stronger in Arctic municipalities. In addition to this, we establish that mines have a positive effect on the number of 20 to $39-$ year-olds in the municipality and that they tend to reduce crime rates. They do not alter the population size, the education or gender compositions in the municipality, or the childbirth rate.

Employment, unemployment, non-labor market, and population size

The first set of results focus on employment, unemployment, the number of people outside the labor force, and population size. The empirical results reveal strong positive and significant effects of a mine opening on employment (Model 1 in Table 4). The employment effects start to show in the years prior to a mine opening and in the year where the mine starts production the effect accumulates to 364 persons. That is, when compared to what employment would have been in the municipality had there been no mine, an additional 364 new jobs have been created in that municipality due to the mine opening. ${ }^{6}$ This employment effect persists and even moderately increases over time such that the employment effect in year three after the mine opening is 436 persons. These effects are not statistically different between Arctic and non-Arctic municipalities as the interaction terms are insignificant.

The strong employment effect is accompanied by a clear drop in unemployment that coincides with the rise in employment (Model 2 in Table 4). This drop, however, is only about half the magnitude of the employment effect pointing toward the possibility that people who were not previously considered part of the labor force now enter the labor market to take up employment. In fact, there is some evidence that such an effect may be present (Model 3 in Table 4), as the point estimates in the model for "Non-labor market" are negative and large and in year three after the mine opening the effect becomes statistically significant.

\footnotetext{
${ }^{6}$ Note that we are measuring the number of employed people in the municipality where the mine is located. This number may differ from the total employment effect of the mine if people commute from other municipalities to work in the mine. See Rolfe et al. (2007) and MMSD (2002) for a discussion.
} 
The empirical results show that a mine opening has no effect on population size (Model 4 in Table 4). The main effects are insignificant and so are the interaction terms. In the year a mine opens the point estimate for the main effect is only 2 with a standard error of 144 .

Thus, there are clear and positive economic effects in municipalities where new mines are established. Employment is clearly increasing and both unemployment and the number of people who are outside the labor market drop. Since there is no significant change in population size, this indicates that the positive employment effects are shared among the locals. To fully make this conclusion, however, a migration study is required, which is not permitted by the municipality-level data that we have available.

\section{Industry composition}

The mining industry is clearly expected to increase in importance when a new mine starts operation. This is confirmed empirically, but only for Arctic municipalities (Tables 5a and 5b). In non-Arctic municipalities a mine opening is not a sufficiently big event to significantly shift the employment share in the mining industry. For Arctic municipalities, however, the shift in employment share is significant. In the year the mine starts operation the employment share in the mining industry increases by 1.6 percentage points. This effect persists and increases to 3.1 percentage points in year three after the mine opening. Hence, mines have a strong influence on the industry structure in Arctic societies.

Other industries are also influenced by mine openings. The construction industry in Arctic municipalities grows significantly as a result of a mine opening. The increase in employment share can be detected up to three years before the mine starts operation, which is only natural as the construction sector is a main contributor to the establishment of the mine. The year before the mine starts operation and in the year where the mine starts production the employment shares allocated to the construction industry are 2.1 percentages points and 1.5 percentage points higher than usual. In the years that follow the mine opening the construction industry reverts back to normal, but then a significant effect starts to show again in year three after the mine opening. This three-year effect is also present in non-Arctic municipalities.

The primary sector also grows as a result of mining activities. In the year before the mine starts production the employment share allocated to the primary sector goes up by a significant 2.4 percentage points and the effect stays at that level during the period we investigate (up to three years after the mine starts production). These strong effects are found for both Arctic and non-Arctic municipalities. We can also establish significant effects for the wholesale and retail industry. In non-Arctic societies the employment share allocated to wholesale and retail increases the year after the mine starts production, but then in year three after the mine starts operation there is a significant drop in the employment share in this industry. All other industries are either unaffected by the mine opening (manufacturing, electricity, transportation, and gas and water supply) or is negatively affected.

\section{Demographic compositions}

It has already been established that a mine opening does not alter the population size in a municipality. In the case of no migration this would naturally imply that we should not expect to see any effects on the age, gender, and human capital compositions following a mine opening. In the case of migration it is less clear what to expect. Our first set of results on this issue is presented in Table 6 . We divide the population into five age groups: $0-19,20-39,40-59,60-79$, and $80+$. The results show that mines have a positive effect on the number of young people in the municipality. Three years prior to the mine opening the number of young people (20-39 years old) starts to increase and the effect stays positive and significant through the year 
where the mine starts producing. After that the point estimates remain positive, but they turn insignificant. All other age groups are unaffected by the mine opening.

Another important dimension to look at is the gender composition in a society. One prior is that mining related employment is a male activity and therefore a new mine would attract more men to the municipality, but there is no evidence of such an effect in the data (Table 7). In fact, there are not significant effects for either men or women. If anything, there is weak evidence for an increasing female proportion when mines open up (see Model 4 in Table 7). The lack of change in the gender composition may also be the reason why we do not find an effect on childbirth rate as a consequence of a mine opening (Model 5 in Table7).

\section{Human capital and crime}

Mines have traditionally relied on unskilled labor (Gylfason, 2001), but more recently mines have become larger and more technically complex, which increases the required skill levels of workers and decreases employment (MMSD, 2002). Hence, the skill composition in a society may likely change as a result of a mine opening. This, however, is not the case in our data, as Table 8 vividly shows. When we estimate our model for the four education levels - basic schooling, upper secondary schooling, tertiary education (short), and tertiary education (long)—we do not establish a single significant coefficient. The abundance of insignificant coefficients clearly shows that a mine opening has no significant influence on the human capital distribution.

Finally, we can establish one additional positive effect from a mine opening: crime drops. Two years before the mine starts production there is a significant drop in the crime rate of 1.1 percentage point. The point estimate stays at this level in the following years but it is statistically insignificant the following two years before it regains its significance in year three, four, and five. This finding contradicts previous findings by Carrington (1996), MMSD (2002) and McMahon and Remy (2001), who report higher crime rates in mine development areas. These studies also find a sizable inflow of workers from outside and link the two. In the Nordic countries a mine opening does not increase the population size significantly, and hence the lack of inflow of new workers may be the reason why we observe crime rates dropping and not increasing.

\section{Discussion}

The empirical analysis shows many positive effects from mining projects in the Nordic countries and more specifically in the Arctic regions of Norway, Sweden, and Finland. The mines create new jobs and as a result both unemployment and the number of people outside the labor force are reduced. The new jobs are established in the mining industry and as derived employment in both construction and the primary sector. We have also provided evidence showing that the number of young people aged 20-39 increases when mines arrive in the area and that crime is reduced. Hence, the overall assessment is that mines are good for local societies, at least in the Arctic regions of the Nordic countries.

An important question is to what extent these results can be transferred to other territories in the Arctic region. That the Nordic countries may be somewhat different from other areas in the Arctic is reflected in the empirical observations that population size is constant despite the opening of a new mine, gender composition is unaffected, and the education distribution in the municipality is unaltered. This indicates that both manpower and knowledge are present in the areas where mines are established, at least to some extent. In other parts of the Arctic this has not been the case. When the Trans-Alaska Pipeline System was built it created a huge labor demand, which resulted in an influx of skilled "pipeliners," where the majority came 
from the pipeline industry in Oklahoma and Texas (Carrington, 1996). The influx of non-Alaskans, a sense of transiency, and rapid changes led to pressure on social welfare: increased crime, accelerated divorce rates, alcoholism, gambling, prostitution, and overcrowded classrooms (Carrington, 1996). The Pine Point Mine in the Northwest Territories of Canada during 1965-1987, for example, was mainly operated by transient mineworkers based in a temporary mining town. Few locals found employment at the mine, but nevertheless they suffered from damaging effects on traditional hunting and trapping grounds in the region (Sandlos and Wiersma, 2000; Locock, Mussieux, and Tyson, 2006). Hence, mine openings in regions where societies lack either manpower or skills will experience additional dynamics to those observed in the Nordic countries.

The situation in Greenland deserves particular attention in this discussion. Greenland has received a lot of global attention in recent time as a new major frontier due to the prospect of exploration and exploitation of significant mineral and hydrocarbon resources (Nuttall, 2012, 2013). For years varying interest groups, such as governmental bodies, advisory groups, and business associations (Government of Greenland, 2014; Ministry of Foreign Affairs, 2011; Økonomisk Råd, 2012; The Committee for Greenlandic Mineral Resources to the Benefit of Society, 2014; Copenhagen Economics, 2012; Nuttall, 2012), have argued that extractive industries and in particular mining and oil development can be the path that Greenland should pursue to improve economic conditions and recover economic growth. Despite the fact that Greenland had mining activities from 1800s up to modern times in the 1990s (Nordregio, 2010; GEUS, 2013) they have been at a modest scale and at present there are limited operating mining activities in Greenland (MLSA, 2016). Hence, unlike the Arctic regions of the Nordic countries, which we study in this paper, it is not clear if Greenland has a workforce of a sufficient scale and with appropriate competences (experience) required to harvest the positive employment effects of a large scale mining project (Økonomisk Råd, 2012; Copenhagen Economics, 2012; The Committee for Greenlandic Mineral Resources to the Benefit of Society, 2014). If this is the case, then Greenland's experience may be more similar to the Nanisivik and Polaris mines in Nunavut, where some (but far below expectations) Inuit from Arctic Bay and Resolute found employment at the mines (Bowes-Lyon, Richards, and McGee, 2009). For a detailed discussion of the Greenlandic case see The Committee for Greenlandic Mineral Resources to the Benefit of Society (2014).

In this paper we have identified positive socioeconomic effects from mining activities. We have not addressed the mines' influences on the environment or the consequences of potentially hazardous working conditions. We have also not addressed the often complex relationships between the mining industry and indigenous people. While there are good examples of how indigenous people and the mining industry cooperate, such as the Red Dog Mine in Alaska (Prno, 2013; Horswill and Sandovik, 2000) and Diavik Diamond Mine in Canada (Missens, Dana, and Anderson, 2007; Ritter, 2001), there are also examples of limited local participation and socioeconomic value creation. See for example the discussion related to the Pine Point Mine in Canada (Sandlos and Wiersma, 2000). Naturally, these potential threats and costs should be internalized and dealt with to secure successful implementation of any mining project.

\section{Conclusion}

In this paper, we establish the socioeconomic effects of mining projects in the Nordic countries with a particular focus on the Arctic region. We find strong positive effects on local employment, a decrease in unemployment, and a reduction in the number of people who are outside the labor force. The positive employment effects can be found in the mining and construction industries and the primary sector, but the timing and magnitude varies in line with the life cycle of the mining project. Our results also show that 
mines have a positive influence on the number of young people in the municipality and that they reduce crime rates.

Our results also show that the gender and education compositions are unaffected by local mining activities and we are unable to detect changes in population size when mines are established in the area. Further research should establish if this is a result that only pertains to Scandinavia and to what extent the Arctic regions of the Nordic countries are different from other Arctic territories. Such studies may, however, be challenged by the lack of high-quality data that has benefitted this study.

In conclusion, this study contributes to the scarce literature on the socioeconomic effects of mining activities in the Arctic. Better knowledge about this issue is warranted as the Arctic is likely to be the resource deposit of the future. It is difficult, however, to answer the important question how Arctic societies change when resource exploration becomes more prevalent in the region. One reason is that data about these territories is limited and the number of mines in the area is small. With this study, we hope to pave the way for more research that will shed light on these our most Northern societies and how they can be expected to change when extractive industries enter the region. 


\section{References}

Aarsæther, N., 2004. Community viability. In Arctic Human Development Report. Akureyri: Stefansson Arctic Institute, pp. 139-154.

AHDR, 2004. Arctic Human Development Report. Einarsson, N., Larsen, J. N., Nilsson, A., Young, O. R. (eds). Stefansson Arctic Institute, Akureyri, Iceland.

AHDR, 2015. Arctic Human Development Report: Regional Processes and Global Linkages. Larsen, J. N., and Fondahl, G. (eds.) Nordic Council of Ministers, Copenhagen.

ASI, 2010. Arctic social indicators-a follow-up to the Arctic Human Development Report. Larsen, J.N., Schweitzer, P., and Fondahl, G. (eds.). TemaNord. Nordic Council of Ministers, Copenhagen.

AMAP, 2010. Assessment 2007: Oil and Gas Activities in the Arctic—Effects and Potential Effects, vol. 1. Arctic Monitoring and Assessment Programme (AMAP), Oslo, Norway.

Aroca, P., 2001. Impacts and development in local economies based on mining: the case of the Chilean II region. Resources Policy, 27(2), 119-134.

Bowes-Lyon, L., Richards, J.P., McGee, T.M., 2009. Socio-economic impacts of the Nanisivik and Polaris mines, Nunavut, Canada. In Richards, J.P., Mining, Society and a Sustainable World. Springer-Verlag Berlin Heidelberg.

Capozza, K. 2005. Red Dog Mine. In Encyclopedia of the Arctic Vol. 3. Routledge, New York, pp. 17481749 .

Carrington, W.J., 1996. The Alaskan labor market during the pipeline era. Journal of Political Economy, 186-218.

Clements, K.W., Ahammad, H., Qiang, Y., 1996. New mining and mineral-processing projects in Western Australia: effects of employment and the macro-economy. Resources Policy, 22(4), 293-346.

Copenhagen Economics, 2012. Mining and sustainable economic growth. Employers' Association of Greenland. http://www.ga.gl/LinkClick.aspx?fileticket=LHEHGwF1EPA\%3d\&tabid=36\&language=da-DK (accessed 26.02.2016).

Cusumano, M., Kahl, S., Suarez, F.F., 2006. Product, process, and service: a new industry lifecycle model. MIT Working Paper 228.

Davis, G.A., 1995. Learning to love the Dutch disease: evidence from the mineral economies. World Development, 23(10), 1765-1779.

Davis, G.A., 1998. The minerals sector, sectoral analysis, and economic development. Resources Policy, 24(4), 217-228.

Davis, G.A., 2010. Extractive economies, growth, and the poor. In Richards, J.P., Mining, Society and a Sustainable World. Springer-Verlag Berlin Heidelberg. 
Domenech, J., 2008. Mineral resource abundance and regional growth in Spain, 1860-2000. Journal of International Development, 20(8), 1122-1135.

Duhaime, G., 2004. Economic systems. In Arctic Human Development Report. Einarsson, N., Larsen, J. N., Nilsson, A., Young, O. R. (eds). Stefansson Arctic Institute, Akureyri, pp. 69-84.

Duhaime, G., Caron, A., 2006. The economy of the circumpolar Arctic. In The Economy of the North. Statistics Norway, Oslo, pp. 17-26.

Eggert, R.G., 2001. Mining and economic sustainability: national economies and local communities. A Study Prepared for the Mining, Minerals, and Sustainable Development Project, Colorado School of Mines.

Ejdemo, T., 2013. Mineral development and regional employment effects in northern Sweden: a scenariobased assessment. Mineral Economics, 25(2-3), 55-63.

FODD, 2012. Mines active in 2012 in Fennoscandia. The Fennoscandian Ore Deposit Database. http://en.gtk.fi/export/sites/en/informationservices/databases/fodd/minesactive.pdf (accessed 03.02.2014).

GEUS, 2013, June. Mineralske råstoffer med fokus på Grønland. Lecture conducted from Ingeniørforeningen, IDA.

Gilberthorpe, E., Papyrakis, E., 2015. The extractive industries and development: the resource curse at the micro, meso and macro levels. The Extractive Industries and Society, 2(2), 381-390.

Government of Greenland, 2014. Greenland's oil and mineral strategy 2014-2018. http://naalakkersuisut.gl/ /media/Nanoq/Files/Publications/Raastof/ENG/Greenland\%20oil\%20and\%20mine ral\%20strategy\%202014-2018_ENG.pdf (accessed 10.01.2015).

Gylfason, T., 2001. Natural resources, education, and economic development. European Economic Review, 45(4), 847-859.

Hajkowicz, S.A., Heyenga, S., Moffat, K., 2011. The relationship between mining and socio-economic well being in Australia’s regions. Resources Policy, 36(1), 30-38.

Harsem, Ø., Eide, A., Heen, K., 2011. Factors influencing future oil and gas prospects in the Arctic. Energy Policy 39(12), 8037-8045.

Heleniak, T., Bogoyavlensky, D., 2015. Arctic populations and migration. In Arctic Human Development Report: Regional Processes and Global Linkages. Larsen, J. N., and Fondahl, G. (eds.) Nordic Council of Ministers, Copenhagen, pp. 53-104.

Hirshberg, D., Petrov, A. N., 2015. Education and Human Capital. In Arctic Human Development Report: Regional Processes and Global Linkages. Larsen, J. N., and Fondahl, G. (eds.). Nordic Council of Ministers, Copenhagen, pp. 349-399.

Horswill, D.H., Sandovik, H., 2000. Mining and sustainable development at Red Dog. Minerals Engineering 52(11), 25-31.

Huntington, H., Weller, G., 2005. An introduction to the Arctic climate impact assessment. In Arctic Climate Impact Assessment. Cambridge University Press, New York, pp. 2-18. 
Huskey, L., Pelyasov, A., 2015. Economic systems. In Arctic Human Development Report: Regional Processes and Global Linkages. Larsen, J. N., and Fondahl, G. (eds.). Nordic Council of Ministers, Copenhagen, pp. 151-183.

Ivanova, G., 2014. The mining industry in Queensland, Australia: some regional development issues. Resources Policy, 39, 101-114.

Jacobson, L.S., LaLonde, R.J., Sullivan, D.G., 1993. Earnings losses of displaced workers. The American Economic Review, 685-709.

Kadenic, M.D., 2015. Socioeconomic value creation and the role of local participation in large-scale mining projects in the Arctic. The Extractive Industries and Society, 2(3), 562-571.

Kullerud, L., 2011. Sustainability: a green Arctic. Nature 478 (7368), 179-180.

Locock, A. J., Mussieux, R., and Tyson, R., 2006. Minerals of the Pine Point Lead-Zinc Deposits Northwest Territories Canada. Rocks \& Minerals, 81(1), 24-32.

Loveridge, S., 2004. A typology and assessment of multi-sector regional economic impact models. Régional studies, 38(3), 305-317.

McMahon, G., Remy, F., 2001. Large mines and the community: socioeconomic and environmental effects in Latin America, Canada, and Spain. The World Bank, Washington, and International Development Research Centre, Ottawa.

MLSA, 2016. The Mineral Licence and Safety Authority (MLSA). List of mineral and petroleum licenses in Greenland. https://www.govmin.gl/images/list_of_licences_20160216.pdf (accessed 26.02.2016).

Ministry of Foreign Affairs, 2011. Denmark, Greenland and the Faroe Islands: Kingdom of Denmark strategy for the Arctic 2011- 2020. Ministry of Foreign Affairs, Copenhagen, Nuuk, Tórshavn. http://usa.um.dk/en/ /media/USA/Arctic_strategy.pdf (accessed 01.09.2013).

Missens, R., Dana, L.P., Anderson, R., 2007. Aboriginal partnerships in Canada: focus on the Diavik diamond mine. Journal of Enterprising Communities: People Places Global Econ. 1(1), 54-76.

MMSD, 2002. Breaking new ground: mining, minerals, and sustainable development. The Report of the Mining, Minerals and Sustainable Development (MMSD) Project, Earthscan Publications, London and Sterling, VA.

Moon, C.J., Evans, A.M., 2006. Ore mineral economics, and mineral exploration. Introduction to Mineral Exploration. Blackwell Publishing, Malden, MA.

Nordregio, 2010. Mobilitet i Grønland, Sammenfattende Analyse. The Nordic Council of Ministers, Stockholm.

Nuttall, M., 2012. Imagining and governing the Greenlandic resource frontier. The Polar Journal, 2(1), 113124.

Nuttall, M., 2013. Zero-tolerance, uranium and Greenland's mining future. The Polar Journal, 3(2), 368-383. 
Økonomisk Råd, 2012. Økonomisk Råds Rapport 2012: Naturressourcer som vækststrategi. Nuuk: Grønlands Økonomiske Råd.

http://naalakkersuisut.gl/ /media/Nanoq/Files/Attached\%20Files/Finans/DK/Oekonomisk\%20raad/konomis k\%20Rds\%20rapport\%202012.pdf (accessed 10.01.2015)

Papyrakis, E., Gerlagh, R., 2007. Resource abundance and economic growth in the United States. European Economic Review, 51(4), 1011-1039.

Prno, J., 2013. An analysis of factors leading to the establishment of a social licence to operate in the mining industry. Resource Policy 38(4), 577-590.

Ritter, A.R.M., (2001). Canada: from fly-in, fly-out to mining metropolis. Chapter 6 in Large Mines and the Community Socioeconomic and Environmental Effects in Latin America, Canada, and Spain. The World Bank, Washington, and International Development Research Centre, Ottawa.

Rolfe, J., Miles, B., Lockie, S., Ivanova, G., 2007. Lessons from the social and economic impacts of the mining boom in the Bowen Basin 2004-2006. Australasian Journal of Regional Studies, 13(2), 134-153.

Rolfe, J., Gregg, D., Ivanova, G., Lawrence, R., Rynne, D., 2011. The economic contribution of the resources sector by regional areas in Queensland. Economic Analysis and Policy, 41(1), 15-36.

Sachs, J.D., Warner, A.M., 1995. Natural resource abundance and economic growth (No. w5398). National Bureau of Economic Research.

Sachs, J.D., Warner, A.M., 1999. The big push, natural resource booms and growth. Journal of Development Economics, 59(1), 43-76.

Sachs, J.D., Warner, A.M., 2001. The curse of natural resources. European Economic Review, 45(4), 827838.

Sandlos, J., Wiersma, Y., 2000. Ghost town: remembering pine point. Beaver (now known as Canada’s History) 80(2), 16-21.

Storey, K., Hamilton, L.C., 2003. Planning for the impacts of megaprojects. Social and Environmental Impacts in the North: Methods in Evaluation of Socio-Economic and Environmental Consequences of Mining and Energy Production in the Arctic and Sub-Arctic, Dordrecht: Kluwer Academic Publishers (in cooperation with NATO Scientific Affairs Division), pp. 281-302.

The Committee for Greenlandic Mineral Resources to the Benefit of Society, 2014. To the benefit of Greenland. University of Greenland, University of Copenhagen. http://news.ku.dk/greenland-naturalresources/rapportandbackgroundpapers/To_the_benefit_of_Greenland.pdf (accessed 10.01.2015).

Tonts, M., Plummer, P., Lawrie, M., 2012. Socio-economic wellbeing in Australian mining towns: a comparative analysis. Journal of Rural Studies, 28(3), 288-301. 


\section{Tables and Figures}

Table 1. Active Mines in Fennoscandia (Norway, Sweden, and Finland)

\begin{tabular}{|c|c|c|c|c|c|c|c|}
\hline Mine & Country & County & Municipality & Lat. $\mathrm{N}$ & Long. E & $\begin{array}{l}\text { When } \\
\text { mined }\end{array}$ & Occurrence \\
\hline Aitik & Sweden & Norrbotten & Gällivare & 67.07 & 20.96 & $1968-$ & $\begin{array}{l}\mathrm{Cu}, \mathrm{Au}, \mathrm{Ag}, \\
\mathrm{Mo}\end{array}$ \\
\hline Kirunavaara & Sweden & Norrbotten & Kiruna & 67.83 & 20.19 & $1864-$ & $\mathrm{Fe}$ \\
\hline Malmberget & Sweden & Norrbotten & Gällivare & 67.18 & 20.67 & $1845-$ & $\mathrm{Fe}$ \\
\hline Tapuli & Sweden & Norrbotten & Pajala & 67.42 & 23.33 & 2012- & $\mathrm{Fe}$ \\
\hline Garpenbergsfältet & Sweden & Dalarna & Hedemora & 60.32 & 16.21 & $1876-$ & $\begin{array}{l}\mathrm{Zn}, \mathrm{Pb}, \mathrm{Ag}, \\
\mathrm{Au}, \mathrm{Cu}\end{array}$ \\
\hline Dannemorafältet & Sweden & Uppsala & Östhammar & 60.20 & 17.86 & $\begin{array}{l}1845- \\
1992, \\
2012-\end{array}$ & $\mathrm{Fe}$ \\
\hline Zinkgruvan & Sweden & Örebro & Askersund & 58.81 & 15.10 & $1849-$ & $\begin{array}{l}\mathrm{Zn}, \mathrm{Pb}, \mathrm{Ag}, \\
\mathrm{Cu}\end{array}$ \\
\hline Björkdal & Sweden & Västerbotten & Skellefteå & 64.93 & 20.59 & $1988-$ & $\mathrm{Au}$ \\
\hline Kristineberg & Sweden & Västerbotten & Lycksele & 65.06 & 18.57 & 1935- & $\begin{array}{l}\mathrm{Zn}, \mathrm{Cu}, \mathrm{Pb}, \\
\mathrm{Au}, \mathrm{Ag}\end{array}$ \\
\hline Renström & Sweden & Västerbotten & Skellefteå & 64.92 & 20.09 & $1948-$ & $\begin{array}{l}\mathrm{Zn}, \mathrm{Cu}, \mathrm{Pb}, \\
\mathrm{Au}, \mathrm{Ag}\end{array}$ \\
\hline Gruvberget & Sweden & Norrbotten & Kiruna & 67.65 & 20.99 & $\begin{array}{l}1860- \\
1892, \\
2010-\end{array}$ & $\mathrm{Fe}$ \\
\hline Maurliden Västra & Sweden & Västerbotten & Skellefteå & 65.06 & 19.52 & $2000-$ & $\begin{array}{l}\mathrm{Ag}, \mathrm{Au}, \mathrm{Cu}, \\
\mathrm{Pb}\end{array}$ \\
\hline Svartliden & Sweden & Västerbotten & Storuman & 64.78 & 17.67 & $2005-$ & $\mathrm{Au}$ \\
\hline Kankberg & Sweden & Västerbotten & Skellefteå & 64.92 & 20.26 & 2012- & $\mathrm{Ag}, \mathrm{Au}, \mathrm{Te}$ \\
\hline Maurliden Östra & Sweden & Västerbotten & Skellefteå & 65.05 & 19.55 & $2010-$ & $\begin{array}{l}\mathrm{Ag}, \mathrm{Au}, \mathrm{Cu}, \\
\mathrm{Zn}\end{array}$ \\
\hline Lovisagruvan & Sweden & Örebro & Lindesberg & 59.72 & 15.17 & $1992-$ & $\mathrm{Pb}, \mathrm{Zn}$ \\
\hline Talvivaara & Finland & Kainuu & Sotkamo & 63.99 & 28.06 & 2008- & $\begin{array}{l}\mathrm{Ni}, \mathrm{Co}, \mathrm{Zn}, \\
\mathrm{Cu},\end{array}$ \\
\hline Siilinjärvi & Finland & $\begin{array}{l}\text { Northern } \\
\text { Savonia }\end{array}$ & Kuopio & 63.12 & 27.74 & 1979- & $\mathrm{P} 2 \mathrm{O} 5$ \\
\hline Kevitsa & Finland & Lapland & Sodankylä & 67.70 & 26.97 & $2012-$ & $\begin{array}{l}\mathrm{Ni}, \mathrm{Cu}, \mathrm{Au}, \\
\text { Pd, Pt }\end{array}$ \\
\hline Kemi & Finland & Lapland & Kemi-Tornio & 65.79 & 24.71 & $1966-$ & $\mathrm{Cr}$ \\
\hline Pyhäsalmi & Finland & $\begin{array}{l}\text { Northern } \\
\text { Ostrobothnia }\end{array}$ & Pyhäjärvi & 63.66 & 26.05 & $1962-$ & $\mathrm{Zn}, \mathrm{Cu}$ \\
\hline $\begin{array}{l}\text { Suurikuusikko } \\
\text { (Kittilä Mine) }\end{array}$ & Finland & Lapland & Kittilä & 67.90 & 25.39 & $2008-$ & $\mathrm{Au}$ \\
\hline Laivakangas & Finland & $\begin{array}{l}\text { Northern } \\
\text { Ostrobothnia }\end{array}$ & Raahe & 64.54 & 24.58 & $2011-$ & $\mathrm{Au}$ \\
\hline Hitura & Finland & $\begin{array}{l}\text { Northern } \\
\text { Ostrobothnia }\end{array}$ & Nivala & 63.85 & 25.05 & $\begin{array}{l}1966, \\
1970- \\
2008, \\
2010-\end{array}$ & Ni, Cu, Co \\
\hline Kylylahti & Finland & North & Polvijärvi & 62.86 & 29.35 & $2011-$ & $\mathrm{Cu}, \mathrm{Au}, \mathrm{Zn}$ \\
\hline
\end{tabular}




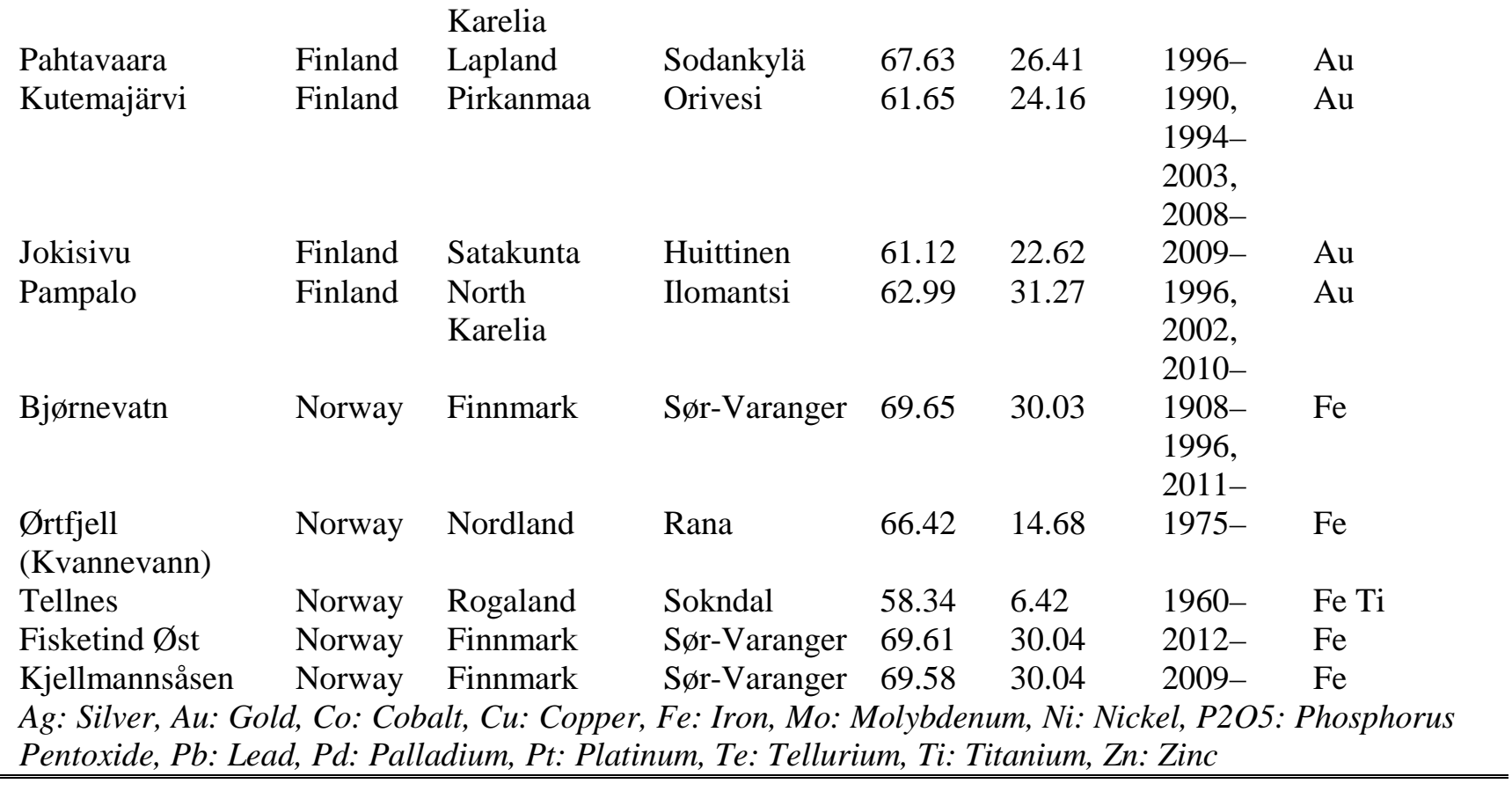


Table 2. Municipalities by Country and Location

\begin{tabular}{lcc}
\hline \hline & Number of municipalities & $\begin{array}{c}\text { Municipality size: Population } \\
\text { Mean (std. dev.) }\end{array}$ \\
\hline \multirow{2}{*}{ All } & 1023 & 18,487 \\
& & $(45,206)$ \\
Arctic & 174 & 9,288 \\
& & $(18,434)$ \\
Non-Arctic & 849 & 20,367 \\
& & $(48,693)$ \\
Norway & 422 & 10,794 \\
Sweden & 290 & $(31,527)$ \\
& & 31,355 \\
Finland & 311 & $(60,139)$ \\
& & 11,034 \\
\hline
\end{tabular}

Note: We exclude the smallest municipalities from the analysis and thus focus on municipalities with 500+ inhabitants. 
Table 3. Description of the Dependent Variables

\begin{tabular}{|c|c|c|}
\hline $\begin{array}{l}\text { Dependent variable (all defined at } \\
\text { the municipality level) }\end{array}$ & $\begin{array}{l}\text { Time period used in the } \\
\text { empirical analysis }\end{array}$ & Description \\
\hline Population & 1995-2012 or 1986-2013 & Population size \\
\hline Employment & 1995-2012 & Number of people employed \\
\hline Unemployment & $1995-2012$ & Number of people unemployed \\
\hline Non-labor market & $1995-2012$ & $\begin{array}{l}\text { People not in the labor market, defined } \\
\text { as: Population - Employment - } \\
\text { Unemployment }\end{array}$ \\
\hline Employment shares by industry (8) & 1995-2012 & $\begin{array}{l}\text { Eight industry dummies are used: } \\
\text { Primary sector; Mining; Manufacturing; } \\
\text { Construction; Electricity, Gas, and } \\
\text { Water supply; Transportation; } \\
\text { Wholesale and retail; and Other }\end{array}$ \\
\hline Age groups (5) & 1986-2013 & $\begin{array}{l}\text { Five age groups are used: } 0-19 ; 20-39 \text {; } \\
\text { 40-59; } 60-79 \text {; and } 80+\end{array}$ \\
\hline Women & 1986-2013 & Number of women \\
\hline Men & 1986-2013 & Number of men \\
\hline Female proportion & 1986--2013 & $\begin{array}{l}\text { The proportion of females defined as: } \\
\text { Women /Population }\end{array}$ \\
\hline Child births & $1986-2013$ & Number of children born \\
\hline Education categories (5) & $1987-2012$ & $\begin{array}{l}\text { Four education groups are used: Basic } \\
\text { schooling; Upper secondary; Tertiary } \\
\text { (short); Tertiary (long) }\end{array}$ \\
\hline Crime & 2007-2012 & $\begin{array}{l}\text { The number of criminal offences } \\
\text { reported to the police }\end{array}$ \\
\hline
\end{tabular}


Table 4. The effect of a mine opening on the population size, employment, unemployment and people not in the labor force.

\begin{tabular}{|c|c|c|c|c|}
\hline & Employment & Unemployment & $\begin{array}{l}\text { Non-labor market } \\
\text { (residual) }\end{array}$ & Population \\
\hline \multicolumn{5}{|l|}{ Prior to opening } \\
\hline \multirow[t]{2}{*}{$t=-3$} & 72.161 & -8.912 & -59.810 & 3.439 \\
\hline & $(97.293)$ & $(17.438)$ & (140.989) & $(51.341)$ \\
\hline \multirow[t]{2}{*}{$t=-2$} & 133.446 & -29.289 & -39.438 & 64.719 \\
\hline & (132.426) & $(52.648)$ & (237.869) & (133.948) \\
\hline \multirow[t]{2}{*}{$t=-1$} & $285.294 *$ & $-93.999 *$ & -159.558 & 31.737 \\
\hline & $(145.488)$ & $(51.185)$ & $(243.410)$ & $(138.412)$ \\
\hline \multicolumn{5}{|l|}{ Mine opening } \\
\hline \multirow[t]{2}{*}{$t=0$} & $364.115 * *$ & $-137.978 * * *$ & -223.961 & 2.176 \\
\hline & $(158.136)$ & $(45.961)$ & (251.636) & $(144.274)$ \\
\hline \multicolumn{5}{|l|}{ Post opening } \\
\hline \multirow[t]{2}{*}{$\mathrm{t}=1$} & $367.208 * * *$ & $-131.018^{* * *}$ & -208.786 & 27.405 \\
\hline & (108.563) & (39.608) & (197.446) & (125.537) \\
\hline \multirow[t]{2}{*}{$t=2$} & $374.967 * * *$ & $-108.974 * * *$ & -253.069 & 12.924 \\
\hline & $(101.832)$ & (39.189) & (185.068) & (107.709) \\
\hline \multirow[t]{2}{*}{$t=3$} & $436.195^{* * *}$ & -70.124 & $-316.747^{* *}$ & 49.324 \\
\hline & (113.873) & (55.533) & $(148.554)$ & (102.875) \\
\hline \multicolumn{5}{|l|}{ Arctic $\times$ Prior to opening } \\
\hline \multirow[t]{2}{*}{$t=-3$} & -69.989 & -18.404 & 141.230 & 52.837 \\
\hline & (158.320) & $(66.875)$ & (155.967) & (71.495) \\
\hline \multirow[t]{2}{*}{$t=-2$} & -205.376 & 28.774 & 173.883 & -2.719 \\
\hline & $(168.284)$ & $(88.051)$ & (249.112) & (140.677) \\
\hline \multirow[t]{2}{*}{$t=-1$} & -185.387 & -1.554 & 243.447 & 56.506 \\
\hline & (193.834) & $(91.264)$ & (259.168) & (144.191) \\
\hline \multicolumn{5}{|l|}{ Arctic x Mine opening } \\
\hline \multirow[t]{2}{*}{$t=0$} & -82.269 & -1.883 & 195.871 & 111.719 \\
\hline & (212.002) & $(98.167)$ & (261.558) & (150.220) \\
\hline \multicolumn{5}{|l|}{ Arctic x Post opening } \\
\hline \multirow[t]{2}{*}{$t=1$} & -78.266 & -14.510 & 205.571 & 112.796 \\
\hline & (176.290) & (101.448) & (209.663) & (134.655) \\
\hline \multirow[t]{2}{*}{$t=2$} & -42.513 & 20.975 & 112.594 & 91.056 \\
\hline & (188.124) & (98.918) & (206.763) & (114.515) \\
\hline \multirow[t]{2}{*}{$t=3$} & -147.754 & 9.539 & 208.195 & 69.981 \\
\hline & (221.794) & (110.914) & (177.924) & $(104.278)$ \\
\hline $\begin{array}{l}\text { Municipality specific time } \\
\text { trends }\end{array}$ & YES & YES & YES & YES \\
\hline Observations & 18,352 & 18,352 & 18,352 & 18,352 \\
\hline R-squared & 0.878 & 0.511 & 0.344 & 0.946 \\
\hline
\end{tabular}

Note: *** 1 percent significance, ** 5 percent significance, and * 10 percent significance. Regressions are based on the period 1995 to 2012. We use robust standard errors in all specifications. 
Table 5a. The effect of a mine opening on the employment share by industry.

\begin{tabular}{|c|c|c|c|c|}
\hline & Primary sector & Mining & Manufacturing & Construction \\
\hline \multicolumn{5}{|l|}{ Prior to opening } \\
\hline \multirow[t]{2}{*}{$t=-3$} & 0.014 & -0.003 & 0.002 & -0.004 \\
\hline & $(0.009)$ & $(0.003)$ & $(0.005)$ & $(0.003)$ \\
\hline \multirow[t]{2}{*}{$t=-2$} & 0.012 & $-0.004^{*}$ & -0.004 & -0.001 \\
\hline & $(0.011)$ & $(0.002)$ & $(0.007)$ & $(0.004)$ \\
\hline \multirow[t]{2}{*}{$t=-1$} & $0.024 * * *$ & -0.002 & -0.005 & -0.005 \\
\hline & $(0.007)$ & $(0.002)$ & $(0.007)$ & $(0.005)$ \\
\hline \multicolumn{5}{|l|}{ Mine opening } \\
\hline \multirow[t]{2}{*}{$t=0$} & $0.028 * * *$ & 0.001 & -0.007 & -0.004 \\
\hline & $(0.009)$ & $(0.004)$ & $(0.007)$ & $(0.006)$ \\
\hline \multicolumn{5}{|l|}{ Post opening } \\
\hline \multirow[t]{2}{*}{$\mathrm{t}=1$} & $0.023 * *$ & 0.007 & -0.007 & -0.003 \\
\hline & $(0.009)$ & $(0.005)$ & $(0.006)$ & $(0.003)$ \\
\hline \multirow[t]{2}{*}{$t=2$} & $0.024^{* * *}$ & 0.004 & -0.007 & 0.000 \\
\hline & $(0.008)$ & $(0.004)$ & $(0.005)$ & $(0.003)$ \\
\hline \multirow[t]{2}{*}{$t=3$} & $0.024^{* * *}$ & 0.001 & -0.004 & $0.008 * *$ \\
\hline & $(0.006)$ & $(0.002)$ & $(0.004)$ & $(0.003)$ \\
\hline \multicolumn{5}{|l|}{ Arctic x Prior to opening } \\
\hline \multirow[t]{2}{*}{$t=-3$} & -0.014 & -0.007 & -0.003 & $0.006^{*}$ \\
\hline & $(0.012)$ & $(0.008)$ & $(0.006)$ & $(0.004)$ \\
\hline \multirow[t]{2}{*}{$t=-2$} & -0.009 & -0.010 & 0.001 & $0.011^{*}$ \\
\hline & $(0.015)$ & $(0.008)$ & $(0.009)$ & $(0.006)$ \\
\hline \multirow[t]{2}{*}{$t=-1$} & -0.011 & -0.004 & -0.001 & $0.021 * * *$ \\
\hline & $(0.013)$ & $(0.008)$ & $(0.009)$ & $(0.008)$ \\
\hline \multicolumn{5}{|l|}{ Arctic x Mine opening } \\
\hline \multirow[t]{2}{*}{$\mathrm{t}=0$} & -0.016 & $0.016^{* *}$ & -0.002 & $0.015^{* *}$ \\
\hline & $(0.013)$ & $(0.007)$ & $(0.009)$ & $(0.007)$ \\
\hline \multicolumn{5}{|l|}{ Arctic x Post opening } \\
\hline \multirow[t]{2}{*}{$t=1$} & -0.010 & $0.017^{*}$ & 0.001 & 0.005 \\
\hline & $(0.013)$ & $(0.010)$ & $(0.008)$ & $(0.004)$ \\
\hline \multirow[t]{2}{*}{$t=2$} & -0.008 & $0.024 * *$ & 0.004 & 0.005 \\
\hline & $(0.014)$ & $(0.011)$ & $(0.007)$ & $(0.005)$ \\
\hline \multirow[t]{2}{*}{$t=3$} & -0.005 & $0.031^{* * *}$ & 0.000 & -0.004 \\
\hline & $(0.013)$ & $(0.012)$ & $(0.009)$ & $(0.004)$ \\
\hline $\begin{array}{l}\text { Municipality specific time } \\
\text { trends }\end{array}$ & YES & YES & YES & YES \\
\hline Observations & 18,352 & 18,352 & 18,352 & 18,352 \\
\hline R-squared & 0.579 & 0.555 & 0.710 & 0.647 \\
\hline
\end{tabular}

Note: *** 1 percent significance, ** 5 percent significance, and * 10 percent significance. Regressions are based on the period 1995 to 2012 . We use robust standard errors in all specifications. 
Table 5b. The effect of a mine opening on the employment share by industry.

\begin{tabular}{|c|c|c|c|c|}
\hline & $\begin{array}{l}\text { Electricity, gas } \\
\text { and water supply }\end{array}$ & Transportation & $\begin{array}{l}\text { Wholesale and } \\
\text { retail }\end{array}$ & Other \\
\hline \multicolumn{5}{|l|}{ Prior to opening } \\
\hline \multirow[t]{2}{*}{$\mathrm{t}=-3$} & 0.003 & -0.001 & $0.005^{*}$ & $-0.016^{* *}$ \\
\hline & $(0.003)$ & $(0.002)$ & $(0.002)$ & $(0.008)$ \\
\hline \multirow[t]{2}{*}{$t=-2$} & 0.003 & -0.000 & 0.006 & $-0.012 * *$ \\
\hline & $(0.003)$ & $(0.002)$ & $(0.004)$ & $(0.005)$ \\
\hline \multirow[t]{2}{*}{$t=-1$} & 0.001 & 0.002 & 0.004 & $-0.019 * * *$ \\
\hline & $(0.003)$ & $(0.003)$ & $(0.003)$ & $(0.004)$ \\
\hline \multicolumn{5}{|l|}{ Mine opening } \\
\hline \multirow[t]{2}{*}{$\mathrm{t}=0$} & 0.002 & 0.002 & 0.002 & $-0.024^{* * * *}$ \\
\hline & $(0.005)$ & $(0.002)$ & $(0.004)$ & $(0.007)$ \\
\hline \multicolumn{5}{|l|}{ Post opening } \\
\hline \multirow[t]{2}{*}{$t=1$} & -0.000 & 0.001 & $0.004^{* *}$ & $-0.024 * * *$ \\
\hline & $(0.003)$ & $(0.001)$ & $(0.002)$ & $(0.009)$ \\
\hline \multirow[t]{2}{*}{$\mathrm{t}=2$} & 0.000 & 0.001 & -0.001 & $-0.022 * * *$ \\
\hline & $(0.003)$ & $(0.002)$ & $(0.002)$ & $(0.008)$ \\
\hline \multirow[t]{2}{*}{$t=3$} & -0.001 & -0.001 & $-0.005 * * *$ & $-0.021 * * *$ \\
\hline & $(0.002)$ & $(0.002)$ & $(0.002)$ & $(0.006)$ \\
\hline \multicolumn{5}{|l|}{ Arctic $x$ Prior to opening } \\
\hline \multirow[t]{2}{*}{$t=-3$} & -0.006 & 0.004 & -0.002 & $0.023^{*}$ \\
\hline & $(0.004)$ & $(0.003)$ & $(0.004)$ & $(0.012)$ \\
\hline \multirow[t]{2}{*}{$t=-2$} & -0.002 & 0.002 & -0.004 & 0.010 \\
\hline & $(0.004)$ & $(0.004)$ & $(0.005)$ & $(0.013)$ \\
\hline \multirow[t]{2}{*}{$t=-1$} & -0.001 & -0.001 & -0.005 & 0.002 \\
\hline & $(0.003)$ & $(0.005)$ & $(0.005)$ & $(0.015)$ \\
\hline \multicolumn{5}{|l|}{ Arctic x Mine opening } \\
\hline \multirow[t]{2}{*}{$\mathrm{t}=0$} & -0.002 & -0.005 & -0.004 & -0.002 \\
\hline & $(0.005)$ & $(0.003)$ & $(0.005)$ & $(0.014)$ \\
\hline \multicolumn{5}{|l|}{ Arctic $\times$ Post opening } \\
\hline \multirow[t]{2}{*}{$t=1$} & 0.001 & -0.006 & $-0.007^{*}$ & -0.002 \\
\hline & $(0.003)$ & $(0.004)$ & $(0.004)$ & $(0.015)$ \\
\hline \multirow[t]{2}{*}{$\mathrm{t}=2$} & 0.002 & -0.007 & -0.003 & -0.017 \\
\hline & $(0.003)$ & $(0.004)$ & $(0.004)$ & $(0.016)$ \\
\hline \multirow[t]{2}{*}{$t=3$} & 0.004 & -0.007 & 0.001 & -0.021 \\
\hline & $(0.002)$ & $(0.004)$ & $(0.005)$ & $(0.019)$ \\
\hline $\begin{array}{l}\text { Municipality specific time } \\
\text { trends }\end{array}$ & YES & YES & YES & YES \\
\hline Observations & 18,352 & 18,352 & 18,352 & 18,352 \\
\hline R-squared & 0.551 & 0.547 & 0.490 & 0.602 \\
\hline
\end{tabular}

Note: *** 1 percent significance, $* * 5$ percent significance, and * 10 percent significance. Regressions are based on the period 1995 to 2012. We use robust standard errors in all specifications. 
Table 6. The effect of a mine opening on the age structure.

\begin{tabular}{|c|c|c|c|c|c|}
\hline & Age 0 to 19 & Age 20 to 39 & Age 40 to 59 & Age 60 to 79 & Age $80+$ \\
\hline \multicolumn{6}{|l|}{ Prior to opening } \\
\hline \multirow[t]{2}{*}{$t=-3$} & -24.128 & $59.246 * *$ & -7.809 & 26.301 & 1.623 \\
\hline & $(41.701)$ & $(26.431)$ & (53.173) & (59.117) & $(9.425)$ \\
\hline \multirow[t]{2}{*}{$t=-2$} & -10.653 & $79.282^{* *}$ & -13.632 & 29.806 & 9.667 \\
\hline & $(54.474)$ & $(36.076)$ & $(60.151)$ & $(56.260)$ & (10.977) \\
\hline \multirow[t]{2}{*}{$t=-1$} & -3.851 & $96.421^{* *}$ & -12.313 & 14.308 & 14.848 \\
\hline & (59.266) & $(45.045)$ & (61.772) & (61.784) & $(9.140)$ \\
\hline \multicolumn{6}{|l|}{ Mine opening } \\
\hline \multirow[t]{2}{*}{$t=0$} & 12.710 & $95.387 * *$ & -31.312 & -11.983 & 14.461 \\
\hline & (64.915) & $(48.111)$ & (73.635) & (68.637) & (13.055) \\
\hline \multicolumn{6}{|l|}{ Post opening } \\
\hline \multirow[t]{2}{*}{$t=1$} & 17.796 & $87.432 *$ & -43.500 & -21.716 & 17.967 \\
\hline & $(69.926)$ & $(47.574)$ & (71.466) & (65.518) & (12.417) \\
\hline \multirow[t]{2}{*}{$t=2$} & 38.801 & 74.473 & -21.911 & -42.319 & $24.951 *$ \\
\hline & (53.132) & (56.193) & $(40.487)$ & $(70.300)$ & (12.938) \\
\hline \multirow[t]{2}{*}{$t=3$} & 42.090 & 63.480 & -27.821 & -45.090 & $28.501 *$ \\
\hline & (50.914) & $(48.881)$ & (45.128) & (54.591) & (15.927) \\
\hline \multicolumn{6}{|l|}{ Arctic $\times$ Prior to opening } \\
\hline \multirow[t]{2}{*}{$t=-3$} & 52.783 & 48.400 & -70.202 & -17.768 & -16.400 \\
\hline & $(63.816)$ & (59.991) & (108.005) & (88.518) & $(13.256)$ \\
\hline \multirow[t]{2}{*}{$t=-2$} & 63.647 & 35.818 & -85.274 & -34.293 & -18.786 \\
\hline & $(79.950)$ & $(61.233)$ & $(137.154)$ & $(95.023)$ & (15.618) \\
\hline \multirow[t]{2}{*}{$t=-1$} & 93.896 & 25.154 & -95.824 & -38.297 & -16.174 \\
\hline & $(92.422)$ & $(70.981)$ & (160.938) & $(105.580)$ & (17.195) \\
\hline \multicolumn{6}{|l|}{ Arctic x Mine opening } \\
\hline \multirow[t]{2}{*}{$t=0$} & 112.022 & 34.451 & -107.600 & -25.982 & -5.831 \\
\hline & (107.611) & $(79.259)$ & (192.795) & $(116.632)$ & $(20.054)$ \\
\hline \multicolumn{6}{|l|}{ Arctic x Post opening } \\
\hline \multirow[t]{2}{*}{$t=1$} & 143.817 & 34.141 & -93.315 & -39.635 & -8.128 \\
\hline & (122.895) & (78.548) & (211.198) & (120.508) & $(21.275)$ \\
\hline \multirow[t]{2}{*}{$t=2$} & 154.914 & 22.289 & -165.343 & -4.816 & -3.853 \\
\hline & $(124.788)$ & $(85.807)$ & (240.725) & (125.568) & $(25.451)$ \\
\hline \multirow[t]{2}{*}{$t=3$} & 75.043 & -15.887 & -5.378 & -57.119 & -19.047 \\
\hline & $(77.053)$ & $(70.030)$ & $(121.235)$ & $(116.951)$ & $(24.860)$ \\
\hline $\begin{array}{l}\text { Municipality specific time } \\
\text { trends }\end{array}$ & YES & YES & YES & YES & YES \\
\hline Observations & 28,466 & 28,466 & 28,466 & 28,466 & 28,466 \\
\hline R-squared & 0.954 & 0.920 & 0.947 & 0.678 & 0.858 \\
\hline
\end{tabular}

Note: *** 1 percent significance, ** 5 percent significance, and * 10 percent significance. Regressions are based on the period 1986 to 2013. We use robust standard errors in all specifications. 
Table 7. The effect of a mine opening on the population size, the gender distribution and child births.

\begin{tabular}{|c|c|c|c|c|c|}
\hline & Population $^{1}$ & Women & Men & $\begin{array}{c}\text { Female } \\
\text { proportion }\end{array}$ & Child births \\
\hline \multicolumn{6}{|l|}{ Prior to opening } \\
\hline$t=-3$ & $\begin{array}{c}55.233 \\
(85.265)\end{array}$ & $\begin{array}{c}21.086 \\
(40.767)\end{array}$ & $\begin{array}{c}34.147 \\
(45.232)\end{array}$ & $\begin{array}{l}-0.001 \\
(0.001)\end{array}$ & $\begin{array}{l}-1.735 \\
(3.966)\end{array}$ \\
\hline$t=-2$ & $\begin{array}{c}94.471 \\
(115.724)\end{array}$ & $\begin{array}{c}38.448 \\
(58.483)\end{array}$ & $\begin{array}{c}56.023 \\
(58.636)\end{array}$ & $\begin{array}{l}-0.001 \\
(0.001)\end{array}$ & $\begin{array}{c}5.249 \\
(9.087)\end{array}$ \\
\hline$t=-1$ & $\begin{array}{c}109.413 \\
(127.541)\end{array}$ & $\begin{array}{c}49.949 \\
(62.945)\end{array}$ & $\begin{array}{c}59.464 \\
(66.030)\end{array}$ & $\begin{array}{l}-0.001 \\
(0.001)\end{array}$ & $\begin{array}{c}0.516 \\
(8.597)\end{array}$ \\
\hline \multicolumn{6}{|l|}{ Mine opening } \\
\hline $\mathrm{t}=0$ & $\begin{array}{c}79.263 \\
(153.499)\end{array}$ & $\begin{array}{c}39.445 \\
(79.200)\end{array}$ & $\begin{array}{c}39.818 \\
(75.874)\end{array}$ & $\begin{array}{l}-0.000 \\
(0.001)\end{array}$ & $\begin{array}{c}10.186 \\
(13.140)\end{array}$ \\
\hline \multicolumn{6}{|l|}{ Post opening } \\
\hline $\mathrm{t}=1$ & $\begin{array}{c}57.979 \\
(151.642)\end{array}$ & $\begin{array}{c}34.713 \\
(78.186)\end{array}$ & $\begin{array}{c}23.267 \\
(74.920)\end{array}$ & $\begin{array}{c}0.001 \\
(0.001)\end{array}$ & $\begin{array}{c}8.971 \\
(13.436)\end{array}$ \\
\hline $\mathrm{t}=2$ & $\begin{array}{c}73.994 \\
(136.982)\end{array}$ & $\begin{array}{c}42.828 \\
(68.305)\end{array}$ & $\begin{array}{c}31.167 \\
(69.752)\end{array}$ & $\begin{array}{c}0.000 \\
(0.001)\end{array}$ & $\begin{array}{c}5.728 \\
(12.140)\end{array}$ \\
\hline$t=3$ & $\begin{array}{c}61.162 \\
(125.617)\end{array}$ & $\begin{array}{c}32.857 \\
(65.932)\end{array}$ & $\begin{array}{c}28.305 \\
(59.937)\end{array}$ & $\begin{array}{c}0.000 \\
(0.001)\end{array}$ & $\begin{array}{c}2.429 \\
(7.402)\end{array}$ \\
\hline \multicolumn{6}{|l|}{ Arctic $x$ Prior to opening } \\
\hline$t=-3$ & $\begin{array}{c}-3.186 \\
(114.312)\end{array}$ & $\begin{array}{c}13.112 \\
(56.403)\end{array}$ & $\begin{array}{l}-16.298 \\
(59.217)\end{array}$ & $\begin{array}{c}0.002^{* *} \\
(0.001)\end{array}$ & $\begin{array}{c}1.894 \\
(7.257)\end{array}$ \\
\hline$t=-2$ & $\begin{array}{c}-38.888 \\
(145.168)\end{array}$ & $\begin{array}{c}-0.570 \\
(73.310)\end{array}$ & $\begin{array}{l}-38.318 \\
(74.100)\end{array}$ & $\begin{array}{c}0.002 \\
(0.001)\end{array}$ & $\begin{array}{c}-6.854 \\
(11.185)\end{array}$ \\
\hline$t=-1$ & $\begin{array}{c}-31.245 \\
(162.456)\end{array}$ & $\begin{array}{c}14.514 \\
(81.355)\end{array}$ & $\begin{array}{l}-45.760 \\
(83.994)\end{array}$ & $\begin{array}{l}0.003 * \\
(0.002)\end{array}$ & $\begin{array}{c}1.751 \\
(9.729)\end{array}$ \\
\hline \multicolumn{6}{|l|}{ Arctic $x$ Mine opening } \\
\hline $\mathrm{t}=0$ & $\begin{array}{c}7.060 \\
(181.780)\end{array}$ & $\begin{array}{c}37.626 \\
(92.595)\end{array}$ & $\begin{array}{l}-30.567 \\
(92.600)\end{array}$ & $\begin{array}{c}0.003 \\
(0.002)\end{array}$ & $\begin{array}{l}-13.176 \\
(14.390)\end{array}$ \\
\hline \multicolumn{6}{|l|}{ Arctic $x$ Post opening } \\
\hline $\mathrm{t}=1$ & $\begin{array}{c}36.881 \\
(181.292)\end{array}$ & $\begin{array}{c}40.378 \\
(93.397)\end{array}$ & $\begin{array}{c}-3.497 \\
(91.850)\end{array}$ & $\begin{array}{c}0.001 \\
(0.002)\end{array}$ & $\begin{array}{c}-4.409 \\
(16.020)\end{array}$ \\
\hline$t=2$ & $\begin{array}{c}3.191 \\
(172.965)\end{array}$ & $\begin{array}{c}25.393 \\
(85.259)\end{array}$ & $\begin{array}{l}-22.202 \\
(92.026)\end{array}$ & $\begin{array}{c}0.001 \\
(0.002)\end{array}$ & $\begin{array}{l}-3.505 \\
(18.067)\end{array}$ \\
\hline $\mathrm{t}=3$ & $\begin{array}{c}-22.388 \\
(173.825)\end{array}$ & $\begin{array}{c}3.161 \\
(87.805)\end{array}$ & $\begin{array}{l}-25.549 \\
(88.606)\end{array}$ & $\begin{array}{c}0.001 \\
(0.002)\end{array}$ & $\begin{array}{c}-1.234 \\
(10.536)\end{array}$ \\
\hline $\begin{array}{l}\text { Municipality specific time } \\
\text { trends }\end{array}$ & YES & YES & YES & YES & YES \\
\hline Observations & 28,466 & 28,466 & 28,466 & 28,466 & 28,466 \\
\hline R-squared & 0.957 & 0.947 & 0.963 & 0.573 & 0.706 \\
\hline
\end{tabular}

Note: $* * * 1$ percent significance, $* * 5$ percent significance, and $* 10$ percent significance. Regressions are based on the period 1986 to $2013 .{ }^{1}$ In contrast to the results presented earlier on population these span the longer time period: 1986 to 2013. We use robust standard errors in all specifications. 
Table 8. The effect of a mine opening on the education level and crime.

\begin{tabular}{|c|c|c|c|c|c|}
\hline & $\begin{array}{c}\text { Basic }^{1} \\
\text { schooling }\end{array}$ & $\begin{array}{c}\text { Upper }^{1} \\
\text { secondary }\end{array}$ & $\begin{array}{c}\text { Tertiary }^{1} \\
\text { (short) }\end{array}$ & $\begin{array}{c}\text { Tertiary }^{1} \\
\text { (long) }\end{array}$ & Crime $^{2}$ \\
\hline \multicolumn{6}{|l|}{ Prior to opening } \\
\hline \multirow[t]{2}{*}{$t=-3$} & -0.000 & 0.000 & -0.001 & 0.000 & 0.005 \\
\hline & $(0.002)$ & $(0.004)$ & $(0.001)$ & $(0.002)$ & $(0.010)$ \\
\hline \multirow[t]{2}{*}{$t=-2$} & -0.002 & 0.002 & 0.001 & 0.000 & $-0.011 * * *$ \\
\hline & $(0.003)$ & $(0.005)$ & $(0.001)$ & $(0.001)$ & $(0.003)$ \\
\hline \multirow[t]{2}{*}{$\mathrm{t}=-1$} & -0.002 & 0.003 & 0.000 & -0.000 & $-0.011^{*}$ \\
\hline & $(0.003)$ & $(0.005)$ & $(0.001)$ & $(0.001)$ & $(0.006)$ \\
\hline \multicolumn{6}{|l|}{ Mine opening } \\
\hline \multirow[t]{2}{*}{$\mathrm{t}=0$} & -0.003 & 0.003 & 0.001 & -0.000 & -0.010 \\
\hline & $(0.004)$ & $(0.006)$ & $(0.001)$ & $(0.001)$ & $(0.006)$ \\
\hline \multicolumn{6}{|l|}{ Post opening } \\
\hline \multirow[t]{2}{*}{$t=1$} & -0.003 & 0.004 & 0.001 & -0.001 & $-0.011^{* *}$ \\
\hline & $(0.003)$ & $(0.005)$ & $(0.001)$ & $(0.001)$ & $(0.004)$ \\
\hline \multirow[t]{2}{*}{$t=2$} & -0.003 & 0.004 & 0.000 & -0.000 & $-0.011 * * *$ \\
\hline & $(0.002)$ & $(0.004)$ & $(0.001)$ & $(0.001)$ & $(0.003)$ \\
\hline \multirow[t]{2}{*}{$t=3$} & -0.002 & 0.003 & 0.000 & -0.000 & $-0.004 * *$ \\
\hline & $(0.002)$ & $(0.004)$ & $(0.002)$ & $(0.001)$ & $(0.002)$ \\
\hline \multicolumn{6}{|l|}{ Arctic $x$ Prior to opening } \\
\hline \multirow[t]{2}{*}{$t=-3$} & -0.001 & 0.001 & 0.001 & -0.000 & -0.003 \\
\hline & $(0.003)$ & $(0.005)$ & $(0.001)$ & $(0.002)$ & $(0.010)$ \\
\hline \multirow[t]{2}{*}{$t=-2$} & -0.001 & 0.000 & 0.000 & 0.000 & 0.000 \\
\hline & $(0.003)$ & $(0.006)$ & $(0.001)$ & $(0.002)$ & $(0.005)$ \\
\hline \multirow[t]{2}{*}{$t=-1$} & -0.000 & -0.001 & 0.000 & 0.001 & 0.002 \\
\hline & $(0.004)$ & $(0.007)$ & $(0.001)$ & $(0.002)$ & $(0.009)$ \\
\hline \multicolumn{6}{|l|}{ Arctic $\times$ Mine opening } \\
\hline \multirow[t]{2}{*}{$t=0$} & -0.001 & -0.000 & -0.001 & 0.002 & -0.000 \\
\hline & $(0.005)$ & $(0.008)$ & $(0.001)$ & $(0.002)$ & $(0.010)$ \\
\hline \multicolumn{6}{|l|}{ Arctic x Post opening } \\
\hline \multirow[t]{2}{*}{$t=1$} & -0.001 & 0.000 & -0.001 & 0.003 & 0.009 \\
\hline & $(0.004)$ & $(0.008)$ & $(0.002)$ & $(0.002)$ & $(0.009)$ \\
\hline \multirow[t]{2}{*}{$t=2$} & -0.002 & 0.002 & -0.002 & 0.002 & -0.006 \\
\hline & $(0.004)$ & $(0.007)$ & $(0.002)$ & $(0.002)$ & $(0.006)$ \\
\hline \multirow[t]{2}{*}{$t=3$} & -0.001 & -0.000 & -0.001 & 0.002 & -0.003 \\
\hline & $(0.004)$ & $(0.008)$ & $(0.003)$ & $(0.002)$ & $(0.005)$ \\
\hline $\begin{array}{l}\text { Municipality specific time } \\
\text { trends }\end{array}$ & YES & YES & YES & YES & YES \\
\hline Number of municipalities & 1,023 & 1,023 & 1,023 & 1,023 & 1,022 \\
\hline Observations & 26,446 & 26,446 & 26,446 & 26,446 & 6,122 \\
\hline R-squared & 0.986 & 0.924 & 0.958 & 0.968 & 0.611 \\
\hline
\end{tabular}

Note: *** 1 percent significance, $* * 5$ percent significance, and $* 10$ percent significance. ${ }^{1}$ Regression is based on the period 2007 to 2012. ${ }^{2}$ Regression is based on the period 1987 to 2012 . We use robust standard errors in all specifications. 